\title{
Ceyhan Nehri (Adana-Türkiye)'nin farklı bölgelerinden yakalanan Afrika kedi balı̆ı̆ (Clarias gariepinus Burchell, 1822)'nda su kalitesinin bazı hematolojik parametreler üzerine etkisi
}

\section{Assessment of pollution indicator some hematological biomarkers in African catfish (Clarias gariepinus Burchell, 1822) living in the Ceyhan River (Adana-Turkey)}

\section{Aysel Şahan* (D) - Sevkan Özütok • Fatma Çevik}

Çukurova Üniversitesi Su Ürünleri Fakültesi, Su Ürünleri Yetiştiriciliği Bölümü, Balık Hastalıkları ABD. 01330 Sarıçam-Balcalı, Adana, Turkey *Corresponding author: ayselsahan2@gmail.com

How to cite this paper:

Şahan, A., Özütok, S. \& Çevik, F. (2017). Assessment of pollution indicator some hematological biomarkers in African catfish (Clarias gariepinus Burchell, 1822) living in the Ceyhan River (Adana-Turkey). Ege Journal of Fisheries and Aquatic Sciences, 34(4):375-382. doi: 10.12714/egejfas.2017.34.4.03

Öz: Bu çalışma, Ceyhan Nehri'nin evsel, mezbaha ve endüstriyel atıklarının deşarj kaynaklarının yakınında bulunan bölge ile aynı nehir üzerindeki Aslantaş Baraj'nın kret altı bölgesinde gerçekleştirimiş̧tir. Çalışmada, su kalitesinin durumu ve bu durumun Afrika kedibalı̆ı (Clarias gariepinus Burchell, 1822)'ndaki bazı hematolojik parametreler üzerindeki etkileri belirlenmiştir. Araștırma, Ceyhan Nehri üzerindeki Aslantaş barajı'nın kret altı bölgesi (istasyon I) ile aynı Nehrin evsel, tarımsal ve endüstriyel atıkların mevcut olduğu (istasyon II) bölgesinde yapılmışıı. Bu iki istasyonda, su sıcaklığı, kimyasal oksijen ihtiyacı (KOI), pH, nitrat ( $\mathrm{NO}_{3-}$ $\mathrm{N}$ ), nitrit $\left(\mathrm{NO}_{2}-\mathrm{N}\right)$, amonyak ( $\mathrm{NH}_{3}-\mathrm{N}$ ) ve çözünmüş reaktif fosfor (ÇRF) değerleri tayin edilmiştir. Araştırma, yaz mevsiminde (Haziran, Temmuz, Ağustos) ve her bir istasyondan 45 adet balık örneklenerek gerçeklestirilmisstir. Ayrıca hematolojik parametrelerden eritrosit (RBC) ve RBC indeksleri (MCV: Ortalama Eritrosit Büyüklüğü, $\mathrm{MCH}$ : Ortalama Eritrosit Hemoglobini, $\mathrm{MCHC}$ : Ortalama Eritrosit Hemoglobin Konsantrasyonu), lökosit (WBC), hemoglobin (Hb), hematokrit (Hct) değerleri ve lökosit hücre formülleri (lenfosit, monosit, nötrofil, eozinofil) ile serum glikoz ve protein seviyeleri gözlenmiştir. İstasyon Il'deki fiziko-kimyasal parametre $\mathrm{KOI}, \mathrm{NH}_{3}-\mathrm{N}, \mathrm{NO}_{2}-\mathrm{N}$, pH ve ÇRF seviyeleri, istasyon l'den daha yüksek bulunmuştur. Çalışmada, Ceyhan Nehri'nin deşarj bölgesinden yakalanan C.gariepinus'ta WBC değerleri ve lökosit hücre formüllerinde çevresel stresörlerden dolayı artışlar, RBC, RBC indeksleri, Hb ve Hct değerlerinde ise azalma tespit edilmiştir $(p<0,05)$. Diğer yandan aynı bölgedeki serum glikoz seviyeleri yükselmiş, protein değerleri ise düşmüştür. Çalışma, sucul ekosistemlerin kirliliklerinin biyolojik takiplerinde, hematolojik parametrelerin rasyonel kullanımları açısından önem arz etmektedir.

Anahtar kelimeler: Afrika Kedi Balı̆ı (Clarias gariepinus Burchell, 1822), Ceyhan Nehri, fiziko-kimyasal parametreler, hematolojik parametreler, kirlilik

\begin{abstract}
This study was carried out in a domestic, slaughter house and industrial discharging region of Ceyhan River and under the crest of the Aslantas Dam on the same river. In this study, the state of water quality and their effects on some hematological parameters of African Catfish (Clarias gariepinus) was identified. Reserach, in the area under the crest of the Aslantaş Dam (station I) located on the Ceyhan River and discharging region on the same river (station II). water temperature, chemical oxygen demand $(\mathrm{COD})$, $\mathrm{pH}$, nitrate $\left(\mathrm{NO}_{3}-\mathrm{N}\right)$, nitrite $\left(\mathrm{NO}_{2}-\mathrm{N}\right)$, ammonia $\left(\mathrm{NH}_{3}-\mathrm{N}\right)$ and soluble reactive phosphorus (SRP) values were determined in these two stations. The study was realised on 45 fish from each station during the summer seasons (June, July, August). The hematological parameters included erythrocyte (RBC) and RBC indices (MCV: mean corpuscular volume, $\mathrm{MCH}$ : mean corpuscular hemoglobin, MCHC: mean corpuscular hemoglobin consentration), leukocyte (WBC), haemoglobine ( $\mathrm{Hb})$, hematocrit $(\mathrm{Hct})$ values and leukocyte cell formulas (lymphocyte, monocyte, neutrophil, eosinophil), serum glucose and protein levels were evaluated. The physico-chemical parameters observed that the water at station II had higher $\mathrm{COD}, \mathrm{NH}_{3}-\mathrm{N}$, $\mathrm{NO}_{2}-\mathrm{N}, \mathrm{pH}$ and SRP than at station I. In this study, WBC values and leukocyte cell formulas of $\mathrm{C}$. gariepinus were found increasing by means of environmental stressors and also, RBC, RBC indices, $\mathrm{Hb}$ and $\mathrm{Hct}$ values were determined decreasing in $\mathrm{C}$. gariepinus collected from station II ( $p<0.05)$. On the other hand, serum glucose levels were increased and protein levels were decreased in station II. The study was found to be important in the biomonitoring of pollution of aquatic ecosystems, in terms of rational use of hematological parameters.
\end{abstract}

Keywords: African Catfish (Clarias gariepinus), Ceyhan River, physico-chemical parameters, hematological parameters, pollution.

\section{Gíiş̧}

Sucul organizmalar için kirlenme, bir stres faktörüdür ve bu nedenle stres faktörlerinin organizmalar üzerindeki olumsuz etkilerini belirlemek ekosistemin geleceği ve besin zincirinde

yer alan tüm canlılar için oldukça önem taşımaktadır (Fırat, 2007; Alak vd., 2012; Arslan, 2015). Doğal ortamlarda yaşayan balıklar, yüzyıllardır, çevre kalite değerlendirmeleri, biyo- 
coğrafik çalışmalar, çevresel kirlilik izleme, değerlendirme ve tür koruma çalışmaları ile su rejimi yönetimi çalışmalarına biyoindikatör olarak dahil edilmişlerdir (Kestemont vd., 2000; Economou vd., 2007; Bashir vd., 2013). Balıkların dokularında kirletici kaynaklı toksik madde birikimine bağlı olarak birçok patolojinin gelişebildiği ve bu birikimin de balıkları tüketen yüksek organizasyonlu canlılar için yaşam tehlikesi oluşturabildiği bildirilmiştir (Arslan, 2015).

Hematoloji, balıkların, fizyolojik durumlarının belirlenmesinin yanı sıra sucul ortamlardaki pestisit kaynaklı kirliliğin balıklarda yarattığı stres düzeyinin belirlenmesi gibi ekolojik durumların tespitinde de yararlanılan önemli bir bilim dalıdır (Azizoğlu ve Cengizler, 1996). Kan hücreleri, balıkların internal veya eksternal çevrelerinde oluşan değişikliklerin tespiti açısından önemli indikatörlerden birisidir. Balıklarda kimyasal kirleticiler ve çevresel etkilerle oluşan ilk değişimler, hematolojik parametrelerden elde edilebileceği gibi bazı biyokimyasal parametrelerdeki dalgalanmalardan da izlenebilir (Stanley ve Omerebele, 2010).

Kan parametreleri, toksik maddelere maruz kalmış balıklarda tüm vücudun pato-fizyolojik indikatörleri olarak ele alındığından yapısal ve fonksiyonel durumların teşhisinde de oldukça önemli yer tutmaktadır. Hematokrit (Hct), hemoglobin $(\mathrm{Hb})$, eritrosit $(\mathrm{RBC})$ ve RBC indeksleri sucul ekosistemdeki metal kirliliği ve kanın oksijen taşıma kapasitesinin en iyi göstergeleri olarak tanımlanır. Ayrıca, balıkta kan plazması ya da serum parametreleri, kirleticilerin etkiledikleri hedef dokuların belirlenmesinde, organizmaların genel sağlık durumları hakkında bilgi eldesinde ve stresli organizmalarda potansiyel hasarın saptanmasında erken uyarıc sistemlerdir (Jacobson-Kram ve Keller, 2001; Adhikari vd., 2004; Fırat, 2007; Arslan, 2015). Eritrosit indeksleri olarak bilinen MCV, $\mathrm{MCH}$ ve $\mathrm{MCHC}$ değerleri, canlılarda eritrosit hücrelerine bağl herhangi bir anomali olup olmadığı veya buna bağlı anemik durumların ortaya çıkarılmasında başvurulan önemli hematolojik indikatörlerdendir. Balıklarda eritrosit indekslerinin çevresel faktörlerden suyun kalitesi, sıcaklığı ve oksijen miktarı gibi değişkenlere karşı duyarlı olduğu, ayrıca RBC miktarındaki artış ve azalışlara bağlı değişkenlik gösterdiği bildirilmiştir (Onusiriuka ve Ufodike, 2000; Stanley ve Omerebele, 2010; Saravanan vd., 2011).

Karabalık, Sekiz bıyık, Karayayın gibi yöresel isimlerlede bilinen ve yetiştiriciliği de yapılan $C$. gariepinus, kirliliğe karşı dirençli, pato-fizyolojik değişimlere hızla cevap verebilen ve ekonomik önemi olan bir türdür (Geldiay ve Balık, 1998; Musa ve Omoriegie, 1999; Appelbaum ve Kamler, 2000; Yalçın vd., 2001; Seith ve Saxena, 2003). C.gariepinus ile ilgili, türün morfometrik özellikleri, nehir kirliliğine karşı göstermiş olduğu hematolojik ve histopatolojik cevaplar ile drenaj sistemlerindeki kirlilik etmenlerinin toksik etkileri üzerine çok sayıda çalışmaya rastlanmıştır (Yeşilbudak vd., 2013; Yalçın vd., 2001; Durmaz Bekmezci, 2010).

Bu çalışmada, Ceyhan Nehri'nin denize yakın bölgesi ile aynı nehir üzerinde kurulu olan Aslantaş Barajı kret altı bölgesindeki su kalitesinin durumu belirlenmiş, bu durumun strese dayanıklı ve bölge pazarına da sunulan, C. gariepinus üzerindeki etkisi hematolojik parametrelerle ortaya çıkarılmıştır.

\section{MATERYAL VE METOT}

\section{Su numuneleri ve balık örneklerinin alınması}

Araştırma, bölgede yıllık periyotlarla yapılmış önceki çalışmalar da gözönünde bulundurularak, kirliliğin üst düzeylere ulaştığı yaz aylarında gerçekleştirilmiştir (Yılmazer ve Yaman, 1999). Su ve balık örnekleri, Ceyhan Nehrinde belirlenen farklı iki istasyondan aylık periyotlarla ve eş zamanlı olarak (Haziran, Temmuz, Ağustos) temin edilmiştir. İlk istasyon; Ceyhan Nehri üzerine kurulu olan ve kirlilikten daha az etkilendiği düşünülen Aslantaş barajı kret altı bölgesindedir. İkinci istasyon ise; nehrin farklı deşarj kaynaklarının yakınında yer alan ve kirliliği farklı çalışmalarla da tespit edilmiş, güney bölgesindedir (Yılmazer ve Yaman, 1999; Anonim, 2010) (Şekil 1). Ceyhan Nehri, tekstil, gıda, tarım ve pamuk üretim sektörünün başını çeken önemli bir endüstriyel merkezdir (Anonim, 2000). Yine aynı bölgede yer alan, Bakü-Ceyhan doğal gaz boru hattı da, bölgeye ayrı bir stratejik ve endüstriyel önem katmaktadır. Diğer yandan hemen hemen yılın dört mevsimi, yoğun zirai aktiviteye maruz kalan bölgenin kirlilikten doğrudan etkilendiği çeşitli araştırmalarla da belirlenmiştir (Yılmazer ve Yaman, 1999; Anonim, 2000; Durmaz Bekmezci, 2010) (Şekil 1).

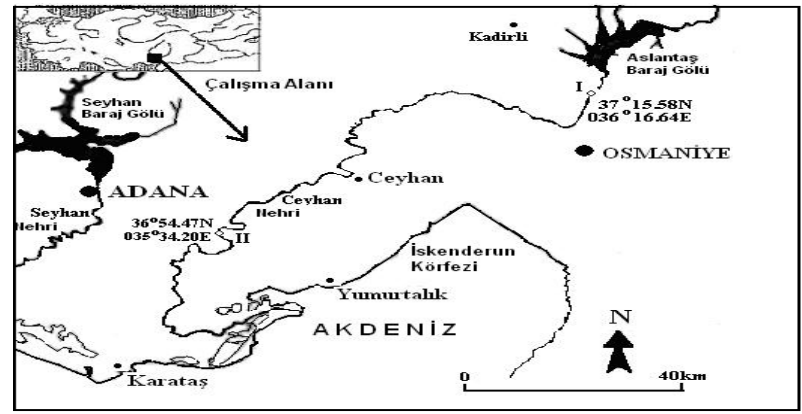

Şekil 1. Ceyhan Nehri ve Örnekleme İstasyonları (I: Aslantaş Barajı Kret alt, II: Ceyhan Nehri)

Figure 1. Ceyhan River and Sampling Stations (I: Under the Crest of the Aslantaş Dam, II: Ceyhan River)

\section{Su analizi}

Su örnekleri, her istasyon için seyreltilmiş $\mathrm{HCl}$ ile 3-4 kez çalkalanmış ve iyice durulanmış, numune kapları yardımıyla üç tekrarlı olarak alınmıştır. Ardından, soğuk zincir altında Çukurova Üniversitesi Su Ürünleri Fakültesi, Su Kalitesi Laboratuvarına taşınmıştır. Suyun sıcaklık ve pH değerleri, dijital pH metre (WTW marka) ile örnekleme alanında ölçülmüştür. Su kalite analizlerinden, Nitrit düzeyi $\left(\mathrm{NO}_{2}-\mathrm{N}\right)$ kolorimetrik yöntem, nitrat düzeyi $\left(\mathrm{NO}_{3}-\mathrm{N}\right)$ kadmiyum indirgeme yöntemi, amonyak düzeyi $\left(\mathrm{NH}_{3}-\mathrm{N}\right)$ fenat yöntemi, çözünmüş reaktif fosfor düzeyi (ÇRF), askorbik asit yöntemi ve kimyasal oksijen intiyacı (KOI) ise, titrimetrik yöntemle tayin edilmiştir (APHA, 1998). Su kalite parametrelerinin kirlilik yönünden 
sonuçları değerlendirilmiş̧tir.

(2003)'e göre

Balık örneklerinin incelenmesi ve hematolojik analizler

Uzatma ağı ve olta kullanılarak her ay 15 adet balık örneklenmiştir. Balıklar, nehir suyuyla doldurulmuş ve oksijenlendirilmiş 250 L'lik tanklarla, Çukurova Üniversitesi Su Ürünleri Fakültesi Balık Hastalıkları laboratuvarlarına taşınmıştır. Balıklara, taşıma sırasında oluşabilecek stresi en aza indirebilmek üzere, banyo tarzında, $15 \mathrm{mg} / \mathrm{L}$ kinaldin (Quinaldine) uygulanmıştır (Küçük vd., 2016). Daha sonra balıklarda, vücut ağılığı ve boy ölçümleri yapılıp, makroskobik ve mikroskobik (paraziter ve mikrobiyal) sağlık taramas gerçekleştirilmiştir (Bauer, 1987; Moravec, 1994; Konuk, 1981). Sağlıklı olduğu belirlenen her bir balığın kuyruk bölgesinden 1 $\mathrm{cm}^{3}$ lük heparinli plastik şırıngalar yardımıyla, kan örnekleri alınmış ve RBC (Eritrosit), WBC (Lökosit), $\mathrm{Hb}$ (Hemoglobin) ve Hct (Hematokrit) tayini için EDTA'lı tüplere aktarılmıştır. Ardından, laboratuvar koşullarında hazırlanan ve aşağıda içeriği verilmiş olan Natt-Herrick solüsyonu ile kan örneklerinin sulandırılmasından sonra RBC ve WBC sayıları, ışık mikroskobunda, Thoma lamı ile belirlenmiştir. $\mathrm{Hb}$ tayininde, Syanmethemoglobin yöntemi kullanılmış, Hct tayini ise mikrohematokrit yöntem ile yapılmıştır (Blaxhall, 1972; Tanyer, 1985).

RBC ve WBC sayılarının tayini için hazırlanan Natt-Herrick solüsyonu (Natt ve Herrick, 1952);

\section{$3,88 \mathrm{~g}$ Sodyum klorür \\ $2,50 \mathrm{~g}$ Sodyum sülfat \\ 2,91 g Disodyum fosfat $12 \mathrm{H}_{2} \mathrm{O}$ \\ 2,25 g Monopotasyum fosfat}

\section{7,50 cc (\%37) Formalin \\ $0,1 \mathrm{~g}$ Metil kırmızısı \\ 1000 cc Distile su}

$\mathrm{RBC}$ indeksleri ise aşağıda gösterildiği şekilde formülize edilip, hesaplanmıştır (Schreck ve Moyle, 1994):

MCV: Ortalama Eritrosit Büyüklüğü $\left(\mu^{3}\right)=\mathrm{Hct} / \mathrm{RBC} \times 10$

$\mathrm{MCH}$ : Ortalama Eritrosit Hemoglobini $(\mathrm{pg})=\mathrm{Hb} / \mathrm{RBC} \times 10$

MCHC: Ortalama Eritrosit Hemoglobin Konsantrasyonu $(\%)=\mathrm{Hb} / \mathrm{Hct} \times 100$

Serum glikoz ve protein tayininde, Kolorimetrik (Spektrofotometre benzeri) yöntemden yararlanılmıştır (Fujimaki ve Isoda, 1990). Diğer yandan balıklardan heparinsiz olarak doğrudan alınan kan örneklerinden yapılan kan yaymaları, My Grünwald-Giemsa karışık boyama tekniğine uygun olarak boyanmıştır (Kocabatmaz ve Ekingen, 1984; Konuk, 1981). Boyalı yaymalar ışık mikroskobu (Olympus $\mathrm{CH}$ 20 ) ile $\times 100$ 'lük objektifte incelenmiştir. Her bir yayma için 100 lökosit sınıflandırılmış ve lökosit hücre formülleri (lenfosit, monosit, nötrofil, eozinofil) yüzde olarak ifade edilmiştir (Fujimaki ve Isoda, 1990).

\section{İstatistiksel analizler}

Sonuçlar ortalama $\% 95$ güven aralığında değerlendirilmiş ve SPSS-17 paket programında $t$-testi uygulanmıştır (Erol, 2010). $P$ değeri $(<0,05)$ önem derecesini göstermektedir.

\section{BULGULAR}

Su analizlerinde, II. istasyona ait tüm su kalitesi parametre değerlerinin, I. istasyona ait değerlerden daha yüksek olduğu tespit edilmiştir (Tablo 1).

Tablo 1. Ceyhan Nehri'nin fiziko-kimyasal özellikleri. I: Aslantaş barajı kret altı, II: Ceyhan nehri. $\mathrm{NO}_{3}-\mathrm{N}$ : $\mathrm{Nitrat} \mathrm{NO}_{2}-\mathrm{N}$ : $\mathrm{Nitrit} \mathrm{NH}_{3}-\mathrm{N}$ : $\mathrm{Amonyak}$ ÇRF: Çözünebilen Reaktif Fosfor, KOi: Kimyasal Oksijen İhtiyacı

Table 1. Physico-chemical oroperties of Ceyhan River. I: Under the crest of the Aslantaş Dam, II: Ceyhan River. $\mathrm{NO}_{3}-\mathrm{N}$ : Nitrate, $\mathrm{NO}_{2}-\mathrm{N}$ : $\mathrm{Nitrite}$, $\mathrm{NH}_{3}-\mathrm{N}$ : Ammonia, SRP: Soluble Reactive Phosphorus, COD: Chemical Oxygen Demand

\begin{tabular}{|c|c|c|c|c|c|c|c|}
\hline \multirow[b]{2}{*}{ İstasyonlar } & \multicolumn{7}{|c|}{ Su Parametreleri } \\
\hline & $\begin{array}{c}\text { Sicaklık } \\
\left({ }^{\circ} \mathrm{C}\right)\end{array}$ & $\mathrm{pH}$ & $\begin{array}{l}\mathrm{NO}_{3}-\mathrm{N} \\
(\mathrm{mg} / \mathrm{L})\end{array}$ & $\begin{array}{l}\mathrm{NO}_{2}-\mathrm{N} \\
(\mu \mathrm{g} / \mathrm{L})\end{array}$ & $\begin{array}{l}\mathrm{NH}_{3}-\mathrm{N} \\
(\mu \mathrm{g} / \mathrm{L})\end{array}$ & ÇRF (mg/L) & $\begin{array}{c}\mathrm{KOI} \\
(\mathrm{mg} / \mathrm{L})\end{array}$ \\
\hline $\mathrm{I}$ & $21,06 \pm 7,4^{*}$ & $8,10 \pm 0,0$ & $0,55 \pm 0,0$ & $0,007 \pm 0,0$ & $0,25 \pm 0,2$ & $0,01 \pm 0,0$ & $8,81 \pm 3,1$ \\
\hline$\|$ & $26,80 \pm 7,5$ & $7,21 \pm 0,0$ & $1,26 \pm 0,0^{*}$ & $0,04 \pm 0,0^{*}$ & $0,45 \pm 0,0^{*}$ & $0,03 \pm 0,1^{*}$ & $37,75 \pm 6,4^{*}$ \\
\hline
\end{tabular}

* İstasyonlararası ayııım $(p<0,05)$. Değerler, ortalama \pm standart sapma olarak tanımlanmıştır

Diğer yandan istasyonlardan yakalanan balıkların ortalama boy-ağırlık değerleri ise sırasıyla, I. istasyon için boy: $44,0 \pm 2,8$ cm., ağırlık: $671,74 \pm 13$ g.; II. istasyon için boy: 44,05 $\pm 1,5 \mathrm{~cm}$., ağırlık: $722,5 \pm 74$ g. olarak ölçülmüştür.

Denemeler süresince istasyonlardan temin edilen balıklar üzerinde yapılan mikroskobik ve makroskobik sağlık taramasında, balıklarda önemli bir bulgu ve olumsuzluğa rastlanmamıştır. Analizlere alınıncaya kadar önemsiz miktarlarda gözlenen mortalite, çalışmayı etkileyecek düzeylerde bulunmamıştır.

Hematolojik analizlerde, II. istasyondan yakalanan balıklardaki tüm parametre değerlerinde, I. istasyon değerlerine göre azalma belirlenirken, WBC ve lökosit hücre formüllerinde önemli düzeyde artış kaydedilmiştir ( $p<0,05)$ (Tablo 2, Tablo 3). 
Tablo 2. Clarias gariepinus'un Hematolojik Parametreleri. I: Aslantaş Barajı kret altı, II: Ceyhan Nehri. Hb: Hemoglobin, Hct: Hematokrit, RBC: Eritrosit, RBC Indeksleri; MCV: Ortalama Eritrosit Büyüklüğü, MCH: Ortalama Eritrosit Hemoglobini, MCHC: Ortalama Eritrosit Hemoglobin Konsantrasyonu

Table 2. Hematological Parameters of Clarias gariepinus. I: Under the Crest of the Aslantaş Dam, II: Ceyhan River. Hb: Haemoglobin, Hct: Hematocrit, RBC: Erythrocyte, RBC Indexis; MCV: Mean Corpuscular Volume, MCH: Mean Corpuscular Haemoglobin, MCHC: Mean Corpuscular Haemoglobin Concentration

\begin{tabular}{|c|c|c|c|c|c|c|}
\hline \multirow[b]{2}{*}{ İstasyonlar } & \multirow[b]{2}{*}{$\begin{array}{c}\mathrm{Hb} \\
(\mathrm{g} / \mathrm{dL})\end{array}$} & \multirow[b]{2}{*}{$\begin{array}{l}\text { Hct } \\
(\%)\end{array}$} & \multirow[b]{2}{*}{$\begin{array}{c}\text { RBC } \\
\left(10^{6} / \mathrm{mm}^{3}\right)\end{array}$} & \multicolumn{3}{|c|}{ RBC Indeksleri } \\
\hline & & & & $\begin{array}{c}\text { MCV } \\
\left(\mu^{3}\right)\end{array}$ & $\begin{array}{c}\mathrm{MCH} \\
(\mathrm{pg})\end{array}$ & $\begin{array}{c}\mathrm{MCHC} \\
(\%)\end{array}$ \\
\hline I & $8,91 \pm 2,4$ & $31,90 \pm 4,7$ & $2,017 \pm 12$ & $171,64 \pm 21,8$ & $48,12 \pm 7,6$ & $25,70 \pm 3,0$ \\
\hline$\|$ & $55,84 \pm 1,3^{*}$ & $24,90 \pm 5,1^{*}$ & $1,833 \pm 58^{*}$ & $133,62 \pm 17,1^{*}$ & $29,07 \pm 5,7^{*}$ & $22,03 \pm 2,6^{*}$ \\
\hline
\end{tabular}

Tablo 3. Clarias gariepinus'un lökosit hücre miktarı ve hücre formülleri. I: Aslantaş Barajı kret altı, II: Ceyhan Nehri. WBC: Lökosit Table 3. Leukocyte cell amount and cell formulas of Clarias gariepinus. I: Under the Crest of the Aslantaş Dam, II: Ceyhan River. WBC: Leukocyte

\begin{tabular}{ccccc}
\hline & & \multicolumn{3}{c}{ Lökosit Hücre Formülleri } \\
\cline { 3 - 5 } İstasyonlar & $\begin{array}{c}\text { WBC } \\
\left(\mathbf{1 0 3} / \mathbf{m m}^{3}\right)\end{array}$ & $\begin{array}{c}\text { Lenfosit } \\
(\%)\end{array}$ & $\begin{array}{c}\text { Monosit } \\
(\%)\end{array}$ & $\begin{array}{c}\text { Nötrofil } \\
(\%)\end{array}$ \\
\hline I & $1055 \pm 30$ & $76,10 \pm 9,8$ & $13,30 \pm 3,5$ & $1,80 \pm 1,4$ \\
II & $3934 \pm 10^{*}$ & $95,60 \pm 2,0^{*}$ & $37,0 \pm 6,1^{*}$ & $5,0 \pm 2,1^{*}$ \\
\hline
\end{tabular}

* istasyonlar arası ayııım $(p<0,05)$. Değerler, ortalama \pm standart sapma olarak tanımlanmıştır.

Balıkların serum protein ve glikoz değerleri de Şekil 2'de gösterilmiştir. Buna göre, II. istasyondaki glikoz değerleri $(146,4 \pm 6,0 \mathrm{mg} / \mathrm{dL})$, I. istasyon değerlerine oranla $(55,30 \pm 6,8$ $\mathrm{mg} / \mathrm{dL}$ ) daha yüksek iken, protein seviyelerinin ise I. istasyona göre $(9,74 \pm 1,8 \mathrm{~g} / \mathrm{dL})$, II. istasyonda daha düşük olduğu $(3,14 \pm 0,9 \mathrm{~g} / \mathrm{dL})$ tespit edilmiştir $(p<0,05)$.

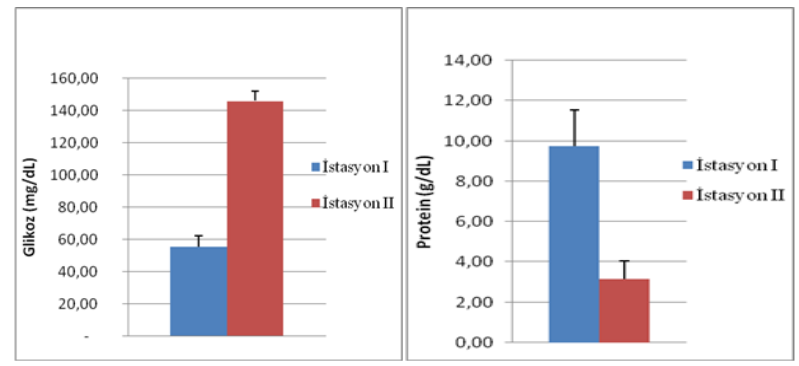

Sekil 2.Clarias gariepinus'un Serum Protein ve Glikoz Seviyeleri. İstasyon I: Aslantaş Barajı kret altı, istasyon II: Ceyhan Nehri

Figure 2. Serum Protein and Glucose Levels of Clarias gariepinus. Station I: Under the Crest of the Aslantaş Dam, Station II: Ceyhan River

\section{TARTIŞMA}

Evsel, endüstriyel ve tarımsal atık sularda bol miktarda bulunan azotlu ve fosforlu bileşikler, sucul sistemlerde kirliliğe neden olan unsurların başında gelmektedir (Güler ve Çobanoğlu, 1997; Aslan vd., 1999; Edwards ve Guillette, 2007). Yılın yaklaşık dört mevsimi yoğunluklu olarak tarımsal atık ile endüstriyel, evsel ve kanalizasyon atıklarına maruz kalan Ceyhan Nehri'nde, demir (Fe), alüminyum ( $\mathrm{Al}$ ), nikel (Ni), kurşun $(\mathrm{Pb})$ ve kadmiyum $(\mathrm{Cd})$ varlığının yüksek olduğu bildirilmiştir (Yılmazer ve Yaman, 1999). Bu araştırmada II. istasyonda, su kalite parametrelerinden $\mathrm{KOI}, \mathrm{NO}_{3}-\mathrm{N}, \mathrm{NO}_{2}-\mathrm{N}$, $\mathrm{NH}_{3}-\mathrm{N}$ ve ÇRF değerleri, Aslantaş Barajı kret altı bölgesinde seçilen I. istasyondaki değerlerden daha yüksek düzeylerde bulunmuştur. Çalışmada, UNESCO/WHO/UNEP (2003)'e göre, II. istasyonun I. istasyona göre kirli olduğu bildirilmiştir.

Havza'da yapılan bir çalışmada noktasal kirlilik kaynaklarının (kentsel yerleşimler, endüstriyel tesisler ve düzenli katı atık depoları) daha küçük bir paya sahip olduğu tarımsal alanlardan gelen kirliliğin ise daha önemli olduğu bildirilmiştir. Aynı çalışmada havzanın denize yakın bölümünde çok kirli su sınıfına girecek ölçüde organik madde ve amonyum yoğunluğu olduğu vurgulanmıştır (Anonim, 2010).

Nitrit genel olarak yüzey sularında $0,001 \mathrm{mg} / \mathrm{L}$ civarındadır. Daha yüksek derişimlerde olması mikrobiyolojik olarak su kalitesinin iyi olmadığını veya endüstriyel etki altında olduğunu düşündürmektedir. Ötrofikasyon için izin verilen nitrat değeri ise $0,2 \mathrm{mg} / \mathrm{L}$ 'dir. Fosfat fosforu derişimi çoğu yüzey sularında 0,005-0,020 mg/L arasında değişmekte ve yüksek derişimleri ötrofikasyona neden olmaktadır (UNESCO/WHO/UNEP, 2003). Araştırma alanından elde edilen değerler ise bu değerlerin üzerinde tespit edilmiştir.

Tayel vd. (2008), Nil Nehri'nde El-Rahawy drenajında yapılan bir çalışmada, çözünmüş inorganik nitrojenin; amonyak, nitrit ve nitratın toplamı olduğunu ve nitratın yüksek konsantrasyonlarının mikrobiyal aktiviteyi de teşvik ettiğini bildirmişlerdir. Ayrıca nehirde, kaydedilen yüksek miktardaki nitrat seviyesinin, nitrifikasyon bakterileri tarafından gerçekleştirilen nitrit-nitrat dönüşümünün bir göstergesi olduğu bildirilmiştir. 
Kanalizasyon suları, yüksek BOI, KOI değerlerine sahip olup, amonyum, fosfat, klorit ve ağır metalleri de yüksek seviyelerde bulundurmaktadır. Kirlilik çalışması yapılan alanlarda genellikle çözünmüş oksijen (ÇO) seviyelerinin düşük olmasının, toksisitenin artmasına yol açtığı ve budurumun da çeşitli toksikantlar için letal konsantrasyon değerlerinin düşmesine neden olduğu bildirilmiştir (Audu vd., 2014). Clarias gariepinus türünün örneklendiği aşağı Seyhan Ovası drenaj kanallarında yapılan bir çalışmada, seçilen beş istasyonda, su kalitesi ve kirleticilerin balıkların karaciğer, kas ve beyin dokularındaki metal birikimi, Glutatyon (GSH) redoks durumu, oksidatif stres ve nörotoksisite oluşturma potansiyelleri ile biyometrik özellikleri incelenmiştir. C. gariepinus'un tüm istasyonlarda balıkların kirliliğe karşı çeşitli adaptasyonlar geliştirdiği ve kirliliğe karşı dayanıklı bir tür olduğu bildirilmiştir (Durmaz Bekmezci, 2010). Ayrıca, Seith ve Saxena (2003), C. gariepinus'un diğer sucul organizmalarda da gözlendiği gibi olumsuz çevre koşullarında, ölçülebilir pato-fizyolojik değişimlerle hızlı cevap verebilen bir tür olduğunu bildirmişlerdir.

Rogers vd. (2003), kurşun toksisitesi ile ilgili araştırmalarında, 72 ve 96 saatlik kurşun uygulamalarında hematolojik parametrelerden $\mathrm{Hb}$ ve $\mathrm{Hct}$ konsantrasyonunda önemli düzeyde azalmalar, protein ve glikoz miktarında ise önemli bir değişim izlememiş̧erdir. Benzer bir çalışmada, Javed ve Usmani (2013), yetiştiricilik havuzlarında, çeşitli ağır metallerin sinerjistik etkisi ile toksik stres ve balık sağlığı bakımından, hematolojik parametrelerin indikatör olarak öneminden bahsetmişlerdir. Ayrıca kirletici unsurlar ile beslenme ve enfeksiyöz hastalıkların, balıklarda hematolojik açıdan değerlendirildiği çeşitli çalışmalarda, eritrosit değerlerinin farklı türden stres kaynakları için güvenilir göstergeler olduğu bildirilmiştir (Rehulka, 2000; Rehulka, 2002a; Rehulka, 2002b Rainza-Paiva vd., 2000; O'neal ve Weirich, 2001; Adeyemo, 2007).

Çalışmamızda kirli olduğu tespit edilen, II. istasyonun bulunduğu bölgeden yakalanan balıklarda $\mathrm{RBC}, \mathrm{Hb}$ ve $\mathrm{Hct}$ değerlerinin önemli düzeyde azaldığı, lökosit hücre miktarının ise önemli artışlar gösterdiği tespit edilmiştir. Su kalitesinin kirleticiler tarafından etkilendiği durumlarda, herhangi bir fizyolojik değişimin, hematolojik parametrelerin bir veya daha fazlası üzerinde yansımaları olacaktır. Yapılan bir çalışmada, sucul ortamda zaman içinde biriken kirlilik faktörlerinin, özellikle sıcaklığın arttığı dönemlerde ortamdaki oksijen düzeyini de düşürmesiyle, hematolojik parametrelerden $\mathrm{RBC}, \mathrm{Hb}$ ve $\mathrm{Hct}$ seviyelerinin doğrudan etkilendiği ve yarı yarıya azaldığ bildirilmiştir (Audu vd., 2014). II. istasyondan tespit edilen RBC, $\mathrm{Hb}$ ve Hct miktarlarının, özellikle sıcaklığın da yüksek olduğu yaz aylarında azalması, yapılan önceki çalışma sonuçlarını da destekler niteliktedir.

Önceki çalışmalarda (Gaber vd., 2013), toksik stres altındaki balıklarda lenfomiyeloid doku'larından lenfositlerin salınımına bağlı olarak lenfopoesis tespit edilmisțir. Bu durum stres altındaki balıklarda lökosit sayısının da artmasına neden olmuştur. Araştırmamızda lökosit hücre formüllerinden lenfosit, monosit ve nötrofil hücrelerin lökosit hücre sayısındaki artışa benzer bir artış gösterdiği bildirilmiştir. Çeşitli stres faktörlerine maruz kalmış balıklarda, immün sistemin canlı üzerindeki koruyuculuğunu ve savunmasını artırmak üzere nötrofil ve monosit hücrelerin artarak savunmaya dahil oldukları izlenmiştir (Hoeger vd., 2004). Pestisitler, içerdiği bileşiğe ve dozuna göre immun sistem üzerine baskılayıcı ya da uyarıcı etkiye sahiptir. Balıklarda kirliliğe bağlı olarak, artan serbest radikallerin, lökositlerin birikmesine ve dolaylı yoldan nötrofil aktivasyonuna neden olduğu bildirilmiştir (Ascherio vd., 2006).

C. gariepinus ile yapılan çeşitli çalışmalarda, çevre kirliliği ile patojen kaynaklı hastalıkların neden olduğu strese bağlı olarak, MCV, MCH ve kan glikoz seviyeleri ile boy ve ağırlık arasında pozitif korelasyon belirlenmiştir (Onusiriuka ve Ufodike, 2000). Stanley ve Omerebele (2010), artan toksik madde konsantrasyonu ile $\mathrm{MCH}$ ve $\mathrm{MCHC}$ düzeylerinin azaldığını kaydetmişlerdir. Çalışmada mikrositik aneminin yanısıra, stres biyo-indikatörlerinden $\mathrm{Hb}$ ve $\mathrm{Hct}$ değerlerinin, eritrositosis'in iki katı azaldığı ve $\mathrm{MCV}, \mathrm{MCH}$ ve $\mathrm{MCHC}$ değerleri ile paralel olarak düştüğü vurgulanmıştır. Benzer düşüşler, formaline maruz kalmış C. gariepinus için de kaydedilmiştir (Okomoda vd., 2010). Saravanan vd. (2011) yaptıkları çalışmada, sazan (Cyprinus carpio)'ları 24 saat süresince, lindan'ın 0,38 ppm'lik dozuna maruz bırakmışlardır. Pestisite maruz kalan balıklarda kontrol grubuna kıyasla MCV, $\mathrm{MCH}, \mathrm{MCHC}$, hemoglobin, hematokrit ve eritrosit değerlerinde düşüş, lökosit sayılarında ise artış meydana geldiğini bildirmişlerdir. II. istasyondan yakalanan balıkların, eritrosit ve eritrosite bağlı hemoglobin ve hematokrit değerleri ile RBC indekslerinde de düşüşler kaydedilmiştir. Elde edilen veriler önceki çalışmalarda bildirilen sonuçları da destekler niteliktedir.

Diğer yandan yapılan çeşitli toksisite çalışmalarında, balıklarda patolojik faktörlerin de etkisiyle eritrosit dejenerasyonlarının oksijen taşınımını etkilediği ve uzun süreli $\mathrm{Hb}$ eksikliğine neden olduğu bildirilmiştir. Bu durumun ise eritrosit hücre membranında yapısal hasarlar bıraktığı, hemoglobin sentezinde aksamalar ve hemolize neden olduğu vurgulanmıştır (Adeyemo, 2007; Gafaar vd., 2010). Okomoda vd. (2013), yaptıkları çalışmada farklı konsantrasyonlardaki $(18,33 ; 20,93$ ve 16,05$)$ bir tür herbisitin karabalıkların (C. gariepinus) hematolojik parametreleri üzerine etkilerini incelemişlerdir. Hemoglobin miktarı, eritrosit sayısı (RBC), trombosit sayısı (PLT) ve paket hücre hacmi (PCV) değerlerinin artan toksikan konsantrasyonuna bağlı olarak azaldığını tespit etmişlerdir.

Glikoz, omurgalı hayvanlarda, yüksek enerjili bir bileşik olup, kas ve karaciğer dokularında glikojen formunda depo edilir. $\mathrm{Bu}$ nedenle kirleticilerin etkisinde kalan sucul organizmaların metabolik ve fizyolojik faaliyetleri ile hematolojik parametrelerde meydana gelen değişimlerin belirlenmesi, ortamdaki kirlilik düzeyini yansıtması bakımından oldukça önem taşımaktadır (Arslan, 2015). Yapılan çalışmalarda, farklı stresörlere maruz kalmış çeşitli balık türlerinde kanda hızlı bir glikoz artışı tespit edilmiştir (hiperglisemi) (Pickering, 1992; Yavuzcan Yıldız ve Polatsu, 1999). Farklı bir çalışmada, serum 
glikoz seviyesindeki artışın, kullanılan medikamentler veya kimyasallara karşı metabolik savunmadaki aşırı enerji intiyacının sonucu olabileceği vurgulanmıştır (Çiftçi vd., 2008). Balıklarda, kan glikoz düzeyinin stres, mevsimler, toksik maddeler, sanayi atıkları ve enfeksiyonlardan doğrudan etkilendiği bildirilmiştir (Çelik, 2008).

Dokuların protein düzeyleri, sucul organizmalarda kimyasalların neden olduğu stres belirteçleri olarak ifade edilmektedir. Serum proteinleri enzimatik taşınım ve hormona işleve sahip olduklarından, kirleticilerden doğrudan etkilenirler. Seyhan ovası drenaj kanallarında C. gariepinus'ta yapılan kirlilik çalışmasında, tarımsal, evsel ve sanayi kirliliğinin protein sentezini baskıladığı bildirilmiştir (Osman vd., 2010) Çalışmamızda serum protein değerlerinin kirli bölgede önemli düzeyde azalma göstermesi, önceki çalışma sonuçları ile uyumludur. Yapılan araştırmalarda serum protein değerlerinin toksik maddeler, hastalıklar, stres, sanayi ve evsel atıklara bağlı kirlilik, su sıcaklığı, mevsimler ve balık türü ile ilgili olduğu bildirilmiştir (Çelik ve Bilgin, 2007).

Diğer yandan stresörler, glikoz, trigliserid veya kolesterol düzeyinde artışlara neden olup, bunun da bir çeşit enerji rezerv artışı olduğu ve organizmanın stresle baş edebilme yeteneğinin göstergesi olarak tanımlanmıştır (Priya vd., 2012). Çalışmamızda, II. istasyona ait glikoz değerlerinin, I. istasyona göre oldukça yüksek olduğu kaydedilmiştir. Glikoz seviyesindeki artışın akut ve subletal olarak uygulanan kirleticilere karşı balığın verdiği genel bir tepki olduğu çeşitli araştırmalar ile de desteklenmiştir. Stres faktörleri ve kas

\section{KAYNAKÇA}

Adeyemo, O.K. (2007). Haematological profile of Clarias gariepinus (Burchell, 1822) exposed to lead. Turkish Journal of Fisheries and Aquatic Sciences, 7: 163-169.

Adhikari, S., Sarkar, B., Chatterjee, A., Mahapatra, C.T. \& Ayyappan, S. (2004) Effects of cypermethrin and carbofuran on certain hematological parameters and prediction of their recovery in a freshwater teleost, Labeo rohita (Hamilton). Ecotoxicology and Environmental Safety, 58:220-226. doi: 10.1016/j.ecoenv.2003.12.003

Alak, G., Atamanalp, M., Uçar, A., Arslan, H., Şensurat, T., Parlak, V. \& Kocaman, E.M. (2012). Kahverengi alabalıklarda (Salmo trutta fario) kadmiyum toksisitesine karşı humik asit etkisinin hematolojik parametrelerle araştırıması. Ege Journal of Fisheries and Aquatic Science, 29(4):181-185. doi: 10.12714/egejfas.2012.29.4.06

Anonim. (2000). Aslantas Dam and related aspects of the Ceyhan River Basin Turkey. A WCD case study prepared as an input to the World Commission on Dams. Agrin Co. Ltd. Cape Town. www.dams.org.

Anonim. (2010). Havza Koruma Eylem Planlarının Hazırlanması Projesi. Ceyhan Havzası, Tübitak Mam Çevre Enstitüsü (Çe). Destekleyen Kuruluş: T.C. Çevre Ve Orman Bakanlığı 432 Sayfa.

APHA (American Public Health Association). (1998). Standard methods for the examination of water and wastewater, $20^{\text {th }}$ Edition, Washington.

Appelbaum, S. \& Kamler, E. (2000). Survival, growth, metabolism and behaviour of Clarias gariepinus (Burchell, 1822) early stages under different light conditions. Aquaculture Engineering, 22:269-287. doi: 10.1016/S0144-8609(00)00054-6

Arslan, H. (2015). Pestisit sinerjisinin; gökkuşağı alabalıklarında (Oncorhynchus mykiss) yüzme performansı, biyokimyasal hematolojik, histopatolojik ve genotoksik etkilerinin araştıııması. Atatürk Üniversitesi, aktivitesi, glikoz miktarının artışı ve fiziksel/kimyasal stres durumlarına bağlı olarak karbonhidrat metabolizmasındaki bozulmaları da tetiklediği bildirilmiştir. (Wedemeyer ve McLeay, 1981; Priya vd., 2012). Çalışma sonuçlarımıza göre, II. istasyonda gözlenen glikoz artışının, balığın kirleticilere karşı verdiği bir tepki olarak değerlendirilebileceği ve bunun da önceki çalışma sonuçlarını destekler nitelikte olduğu bildirilmiştir.

\section{SONUÇ}

Bu çalışmada, çeşitli kirlilik faktörüne maruz kalmış balıklarda, önemli sağlık göstergelerinden biri olan hematolojik parametrelerin, belirleyici etkisini ortaya koyabilmek ve hematolojinin bu yöndeki kullanılabilirliğini belirlemek en önemli hedef olmuştur.

Değerlendirmelere göre, evsel, sanayi, endüstriyel, tarımsal ve mezbaha atıklarının yoğunluklu olduğu Ceyhan Nehri (II. istasyon)'nden yakalanan balıklarda, sağlık göstergesi hematolojik parametrelerde azalmalar, savunma hücrelerinde ise artış tespit edilmiştir. Diğer yandan stres indikatörü serum glikoz ve protein değerlerinde ise önemli dalgalanmalar tayin edilmiştir. Kirliliğe maruz kalmış $C$. gariepinus'ta, hematolojik ve biyokimyasal açıdan tespit edilen önemli düzeydeki değişikliğin, balıklarda herhangi bir fizyolojik bozukluk, hastalık veya ölüm vakasına neden olmadığı belirlenmiştir. $\mathrm{Bu}$ durum, balığın türl özelliğine bağlı olarakgösterdiği adaptasyon ve direnç mekanizmasıyla her türlü koşulda verdiği uyumsal tepki olarak değerlendirilmiştir.

Fen Bilimleri Enstitüsü, Doktora Tezi, Su Ürünleri Mühendisliği Anabilim Dalı, Erzurum.

Ascherio, A., Chen, H., Weisskopf, M. G., O'Reilly, E., McCullough, M. L., Calle, E. E., Schwarzschild, M. A. \& Thun, M. J. (2006). Pesticide exposure and risk for Parkinson's disease. Annals of Neurology, 60(2):197-203. doi: 10.1002/ana.20904

Aslan, G., Tumbat, G., Soyupak, S. \& Yurteri, C. (1999). Aşağı Seyhan havzasında besin maddesi taşınımı. Turkish Journal of Engineering and Environmental Science, 23:261-271.

Audu, B.S., Adamu, K. M. \& Nonyelu, O.N. (2014). Changes in haematological parameters of Clarıas garıepınusexposed to century plant (Agave americana) leaf dust. International Journal of Applied Biological Research, 6(1):54-65

Azizoğlu, A. \& Cengizler, İ. (1996). Sağlıklı Oreochromis niloticus (L.) bireylerinde bazı hematolojik parametrelerin saptanması üzerine bir araştırma. Turkish Journal of Veterinary and Animal Sciences, 20:425431

Bashir, N. Y., Lockwood, P., Chasteen, A. L., Nadolny, D. \& Noyes, I. (2013). The ironic impact of activists: Negative stereotypes reduce social change influence. European Journal of Social Psychology, 43:614-626. doi: 10.1002/ejsp.1983

Bauer, O.N. (1987). Key to the parasites of freshwater fishes of the fauna USSR, Part 3, Nauka, Leningrad, $583 p$.

Blaxhall, P.C. (1972). The haematological assessment of the health of freshwater fish, Journal of Fish Biology, 4:593-604. doi: 10.1111/j.1095-8649.1972.tb05704.x 
Çelik, E.Ş. \& Bilgin, S. (2007).Bazı balık türleri için kan protein ve lipidlerinin standardizasyonu. Erciyes Üniversitesi Fen Bilimleri Enstitüsü Dergisi, 23 $(1-2): 215-229$.

Çelik, E.Ş. (2008). Balık türleri için kan glukozunun standardizasyonu. Su Ürünleri Mühendisleri Derneği Dergisi, 1:38-41.

Çiftçi, N., Cicik, B., Erdem, C. \& Ay, Ö. (2008). Effects of lead concentrations on sera parameters and hematocrit levels in Anguilla anguilla (Linnaeus, 1758). Journal of Fisheries Sciences, 2(4):616-622.

Durmaz Bekmezci, H. (2010). Așağı Seyhan ovası drenaj sistemlerindeki kirlilik etmenlerinin Clarias gariepinus'ta toksik etkileri. Çukurova Üniversitesi Fen Bilimleri Enstitüsü, Biyoloji AnaBilim Dalı, Doktora Tezi. Adana.

Economou, A.N., Giakoumi, S., Vardakas, L., Barbieri, R., Stoumboudi, M. \& Zogaris, S. (2007). The freshwater Ichthyofauna of greece-an update based on a hydrographic basin survey. Mediterranean Marine Science, 8(1):91-166. doi: $10.12681 / \mathrm{mms} .164$

Edwards, T.M. \& Guillette, L.J. (2007). Reproductive characteristics of male mosquito fish (Gambusia holbrooki) from nitrate-contaminated springs in Florida. Aquatic Toxicology, 85(1):40-47.

Erol, H. (2010). SPSS paket programı ile istatistiksel veri analizi. Nobel KitapEvi. 167-210. doi: 10.1016/j.aquatox.2007.07.014

Fırat, Ö. (2007).Oreochromis niloticus'ta metal (Zn, Cd) ve metal karışımının $(\mathrm{Zn}+\mathrm{Cd})$ kan dokusunda fizyolojik ve biyokimyasal parametreler üzerine etkisi. Doktora Tezi, Fen Bilimleri Enstitüsü, Adana

Fujimaki, Y. \& Isoda, M. (1990). Fine-structural of leukocytes in the goldfish, Carassius auratus. Journal of Fish Biology, 36:821-831. doi: 10.1111/j.1095-8649.1990.tb05630.x

Gaafar, A.Y., El-Manakhly, E.M., Soliman, M.K., Soufy H., Mona, S.Z. Mohamed, S.G. \& Hassan, S.M. (2010). Some pathological, biochemical and haematolocal investigations on Nile Tilapia (Oreochromis niloticus) following chronic exposure to edifenphos pestiside. Journal of American Science, 6(10):542-551.

Gaber, H.S., El-Kasheif, M.A., Ibrahim, S.A. \& Authman, M.M.N. (2013). Effect of water pollution in el-rahawy drainage canal on hematology and organs of freshwater fish Clarias gariepinus. World Applied Science Journal, 21:329-341

Geldiay, R. \& Balık, S. (1998). Türkiye"nin tatııu balıkları. Ege Üniversitesi Fen Fakültesi Kitaplar Serisi, No: 37, İmir.

Güler, Ç. \& Çobanoğlu, Z. (1997). Pestisitler. Çevre sağlığı temel kaynak dizisi. No: 52. T.C. Sağlık bakanlığı, sağlık projesi genel koordinatörlüğü. ISBN 1975-8088-69-6, Illköz matbaası I. Baskı. Ankara.

Hoeger, B., Koellner, B., Kotterba, G., Van den Heuvel, M.R., Hitzfeld, B. \& Dietrich, D.R. (2004). Influence of chronic exposure to treated sewage effluent on the distribution of white blood cell populations in rainbow trout (Oncorhynchus mykiss) spleen. Toxicological Sciences, 82:97-105 doi: 10.1093/toxsci/kfh250

Jacobson-Kram, D. \& Keller, K. A. (2001). Toxicology testing handbook. Marce Dekker Ed., New York.

Javed, M. \& Usmani, N. (2013). Haematological indices of Channa punctatus as an indicator of heavy metal pollution in waste water aquaculture pond Panethi, India. African Journal of Biotechnology, 12:520-525. doi: 10.5897/AJB12.2115

Kestemont, P., Didier, J., Depiereux, E. \& Micha, J.C. (2000). Selecting Ichthyological metrics to assess river basin ecological quality. Archiv für Hydrobiologie, 121:321-348.

Kocabatmaz, M. \& Ekingen, G. (1984). Standardization of haematological methods and taking blood from various fish species. Journal of Natural Science, 2:149-159.

Konuk, T. (1981). Practical Physiology, Veterinary Faculty, 181p.

Küçük, S., Öztürk, S. \& Çoban, D. (2016). Su ürünlerinde kullanılan anestezikler. Adnan Menderes Üniversitesi Ziraat Fakültesi Dergisi, 13:7985. doi: 10.25308/aduziraat.294075

Moravec, F. (1994). Parasitic nematodes of freshwater fishes of Europe, Prag., 473p.
Musa, S.O. \& Omoregie, E. (1999). Haematological changes in the mudfish, Clarias gariepinus(Burchell), exposed to malachite green. Journal of Aquatic Science, 14:37-42. doi: 10.4314/jas.v14i1.19971

Natt, M.P. \& Herrick, C.A. (1952). A New Blood Diluent for Couting the Erytrocytes and Leucocytes of the Chicken. Poult. Sci., 31:735-738. doi: $10.3382 / p s .0310735$

Okomoda, J., Ayuba, V.O. \& Omeji, S. (2010). Heamatological changes of Clarias gariepinus (Burchell, 1822) fingerlings exposed to acute toxicity of formalin. Publication of Nasarawa State University, Keffi PAT.

Okomoda, V.T., Ataguba, G.A. \& Ayuba, V.O. (2013). Hematological response of Clarias gariepinus fingerlings exposed to acute concentrations of sunsate. Journal of Stress Physiology \& Biochemistry, 9(2):271-278.

O'Neal, C.C. \& Weirich, C.R. (2001). Effects of low level salinity on prod. and haematological parameters of channel catfish (Ictalurus punctatus) reared in multicrop ponds. Aquaculture International Triennial Conference of World Aquaculture Society, 21-25. In: Book of abstract.

Onusiriuka B.C. \& Ufodike, E.B.C. (2000). Effects of sublethal concentrations of akee apple, Blighia sapida and sausage plant, Kigelia Africana on tissue chemistry of African catfish Clarias gariepinus. Journal of Aquatic Science, 15:47-49. doi: 0.4314/jas.v15i1.19987

Osman, R.W., Munguia, P. \& Zajac, R.N. (2010). Ecological thresholds in marine communities: theory, experiments and management. Marine Ecology Progress Series, 413:185-187. doi: 10.3354/meps08765

Pickering, A.D. (1992). Rainbow trout husbandry: management of the stress response. Aquaculture, 100:125-139. doi: 10.1016/0044-8486(92)90354-N

Priya, B.P., Rachel, V. \& Maruth, Y.A. (2012). Acute toxicity effect of imidacloprid insecticide on serum biochemical parameters of fresh water teleost Channa punctatus. International Journal of Integrative Sciences, Innovation and Technology, 1(2):18-22.

Rainza-Paiva, M.J.T., Ishikawa, C.M., Das Eiras, A.A. \& Felizardo, N.N. (2000). Haemotological analysis of Chara, Pseudoplatystoma fasciatum in captivity. Responsible aquaculture in the new millennium. European Aquaculture Society Special Publication, 28: 590.Nice, France

Rehulka, J. (2000). Influence of astaxanthin on growth rate, condition and some blood indices of rainbow trout, Oncorhynchus mykiss. Aquaculture, 190:27-47. doi: 10.1016/S0044-8486(00)00383-5

Rehulka, J. (2002a). Aeromonas causes severe skin lesions in rainbow trout (Oncorhynchus mykiss): Clinical pathology, haematology and biochemistry. Acta Veterinary Brno, 71:351-360. doi: 10.2754/avb200271030351

Rehulka, J. (2002b). Effect of polychlorinated biphenyls Delor 103 on some haematological and biochemicalindices of the blood plasma of the rainbow trout, Oncorhynchus mykiss (Walbaum). In: The second PCB workshop. Brno, Czech Republic. (Book of Abstracts): 36

Rogers, J.T., Richards, J.G. \& Wood, C.M. (2003). Ionregulatory disruption as the acute toxic mechanism for lead in the rainbow trout. Aquatic Toxicology, 64(2):215-34. doi: 10.1016/S0166-445X(03)00053-5

Saravanan, M., Prabhu Kumar, K. \& Ramesh, M. (2011). Haematological and biochemical responses of freshwater teleost fish Cyprinus carpio (Actinopterygii: Cypriniformes) during acute and chronic subletal exposure to lindane. Pesticide Biochemistry and Physiology, 100(3):206-211. doi: 10.1016/j.pestbp.2011.04.002

Schreck, C.B. \& Moyle, P.B. (1994). Methods for Fish Biology. AmericanFisheries Society. Exxon Company. Maryland, U.S.A. 313

Seith, N. \& Saxena KK. (2003). Haematological responses in a freshwater fish, Channa punctatus due to fenvalerate. Bulletin Environmental Contamination Toxicology, 7:1192-9.

Stanley, O.N. \& Omerebele, U.A.M. (2010). Changes in the hematological parameters of Clarias gariepinus exposed to lead poisoning. Journal of Fsheries International, 5(4):72-76. doi: 10.3923/fish.2010.72.76

Tanyer, G. (1985). Hematoloji ve laboratuvar. Ayyıldı matbaası. Ankara, 441.

Tayel, S.I., Yacoub, A.M. \& Mahmoud, S.A. (2008). Histopathological and haematological responses to freshwater pollution in the Nile catfish Clarias 
gariepinus. Journal of Egyptian Academic Society for Environmental Development, 9 (4):43- 60.

UNESCO/WHO/UNEP. (2003). Water Quality Assessments - A Guide to Use of Biota, Sediments and Water in Environmental Monitoring -Second Edition, Edited by Deborah Chapman 609 pp.

Wedemeyer, G. A. \& McLeay, D. J. (1981). Methods for determining the tolerance of fishes to environmental stressors. In A. D. Pickering (ed.), Stress and fish Academic Press, New York., 247-275.

Yalçın, S., Akyurt, I. \& Solak, K. (2001). Certain reproductive characteristics of the catfish (Clarias gariepinus Burchell, 1822) living in the River Asi (Turkey). Turkish Journal of Zoology, 25:453-460.
Yavuzcan YIldiz, H. \& Polatsu, S. (1999). Evaluation of the secondary stres response in healthy Nile tilapia (Oreochromis niloticus, L.) after treatment with a mixture of formalin, malachite green and methylene blue. Aquaculture Research, 30:379-383.

doi: 10.1046/j.1365-2109.1999.00341.x

Yeşilbudak, B., Duran, S., Tunçsoy, M. \& Erdem, C. (2013). Some morphometric properties of Clarias gariepinus (Burchell, 1822) population in Aslantaş dam lake (Osmaniye). Journalof Aquaculture Engineering and Fisheries Research, 9(2):1-7.

YIImazer, D. \& Yaman, S. (1999). Heavy metal pollution and chemical profile of Ceyhan river (Adana-Turkey). Turkish Journal of Engineering and Environmental Science, 23:59-61. 